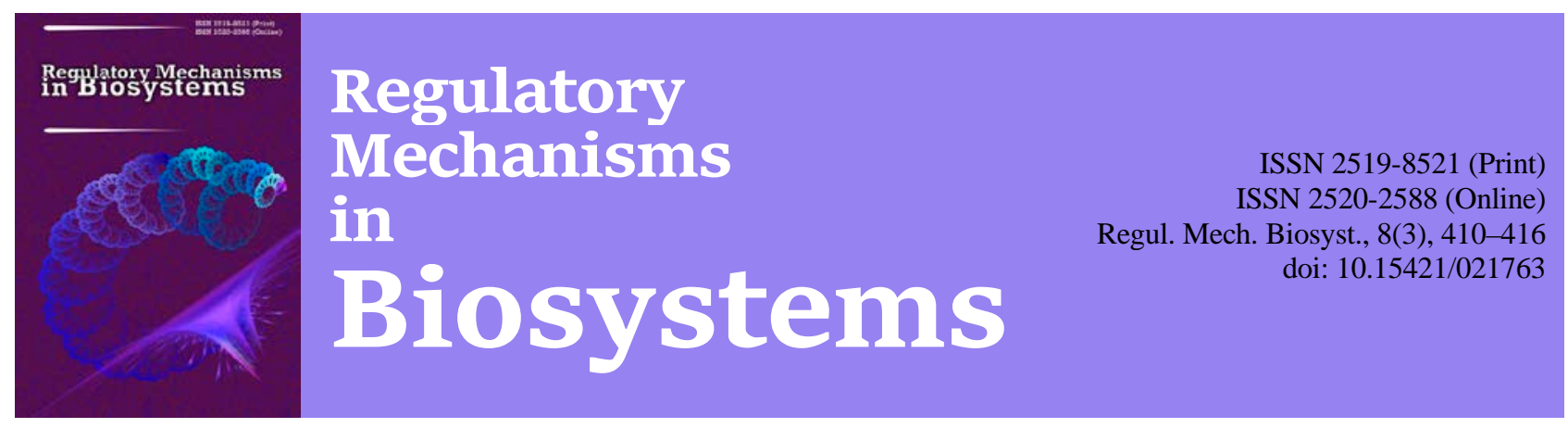

\title{
Endemic course of epidemic diarrhea of pigs in the stabilized focus of infection
}

\author{
D. M. Masiuk*, O. I. Sosnitsky*, V. S. Nedzvetsky****, A. V. Kokarev*, S. G. Koliada* \\ *Dnipro State Agrarian and Economic University, Dnipro, Ukraine \\ **Oles Honchar Dnipro National University, Dnipro, Ukraine \\ ***Bingol University, Bingol, Turkey
}

\section{Article info}

Received 02.07.2017

Received in revised form 11.08.2017

Accepted 17.08.2017

Dnipro State Agrarian and Economic University, Sergei Efremov Str., 25 , Dnipro, 49600, Ukraine. Tel.+38-056-236-17-14. E-mail: plppm@ua.fm

Oles Honchar Dnipro National University, Gagarin Ave., 72, Dnipro, 49010, Ukraine.

E-mail:

nedzvetskyvictor@gmail.com

Bingol University, Selahaddin-i Eyyubi Mah. Aydinlik Cad. 12000, Bingol, Turkey.
Masiuk, D. M., Sosnitsky, O. I., Nedzvetsky, V. S., Kokarev, A. V., \& Koliada, S. G. (2017). Endemic course of epidemic diarrhea of pigs in the stabilized focus of infection. Regulatory Mechanisms in Biosystems, 8(3), 410-416. doi: 10.15421/021763

Porcine epidemic diarrhea virus (PEDV) has been circulating in Ukraine since 2014 and induces an especially dangerous viral infection with a lethal diarrheal syndrome in newborn piglets, with the initial appearance at the focus of infection. The number of infected cases and lethality among diseased piglets of 1-5 days of age can reach $100 \%$, which together with the forced anti-epizootic measures brings significant economic losses. PED can spread to all pigs, but the emergent quality of infectious pathology appears in newborn piglets. No effective and biologically safe means of specific antiviral prophylaxis, which substantially halts the epizootic process is registered, and etiopathogenetic therapy is not developed, therefore PED is an emergent infection which is difficult to control. Over time there appear stationary foci of infection, where evolutionary changes in relationships in the host-parasite system take place fairly rapidly, since pigs are prolific and fast maturing animals able to replace each generation up to three times each year. This leads to a significant variability in interpopulation relationships and the induction of biodiversity in the molecular mechanisms of adaptation and processing of the viral genome. Clinically, genetic modifications of local variants of PEDV populations are manifested in the form of changes in epizootic peculiarities in the course of infectious pathology in different age groups of animals. Modifications of PEDV may be accompanied by a slight weakening of the intensity of the infectious process, a decrease in mortality and a decrease in the severity of the pathogenesis of diarrheal syndrome. At the same time, the age range of severe abdominal lesions expands from newborn piglets to fattening animals of older age groups of 28, 32, 70 days. Using a set of measures to combat the PED, including "reverse feeding" recycled infected biomaterial from convalescent pigs, eradication of the pathogen from the environment of the host macroorganisms through a total disinfection regime and strict compliance with veterinary and sanitary rules of animal husbandry provide temporary positive results, but in theory this approach is incorrect, since contamination of animals leads to the dispersal of the virus and the formation of endemic foci of infection. The persistence of the virus in convalescent organisms is not fixed, the external inanimate environment can only be a mechanical factor in transmission of the pathogen preserving the viability of PEDV over time. Stabilization of the epizootic foci of infection is possible due to three factors: a) dissemination of the virus in "reverse feeding"; b) preservation of the virus in the external environment as a result of poor-quality disinfection; c) occurrence of a non-immune element among the convalescent young gilts, who as a result of juvenile insufficiency of the immune system have a low titer accumulation of colostral antibodies to the virus received in the biomaterial through reverse feeding. Due to the lack of "lactogenic immunity", neonatal pigs as biological indicators for the presence of PEDV in the environment begin reproducing the virus in the enterocytes and develop a typical diarrheal syndrome PED.

Keywords: PED; PEDV; genome-equivalent; PCR-RT; ELISA

\section{Эндемическое течение эпидемической диареи свиней в стабилизированном очаге инфекции}

\author{
Д. Н. Масюк*, А. И. Сосницкий*, В. С. Недзвецкий**, ***, А. В. Кокарев*, С. Г. Коляда* \\ *Днепровский государственный аграрно-экономический университет, Днепр, Украина \\ **Днепровский наииональный университет имени Олеся Гончара, Днепр, Украина \\ ***Бингельский университет, Бингель, Туричия
}

Вирус эпидемической диареи свиней (Porcine epidemic diarrhea virus, PEDV) циркулирует в Украине с 2014 года и индуцирует особо опасный вирусный зооноз - эпидемическую диарею свиней (ЭДС) с летальным диарейным синдромом у новорожденных поросят, при первичном возникновении очага инфекции. Количество инфицированных и летальность среди заболевших поросят 1-5-дневного возраста 
может достигать 100\%, что в совокупности с вынужденными противоэпизоотическими мероприятиями приносит значительные экономические убытки. ЭДС может распространяться на все поголовье свиней, но эмерджентные качества инфекционная патология проявляет на новорожденных поросятах. Эффективных и биобезопасных средств специфической антивирусной профилактики, кардинально обрывающих эпизоотический процесс, не зарегистрировано, а этиопатогенетическая терапия не разработана, поэтому ЭДС является трудно контролируемой эмерджентной инфекцией. С течением времени возникают стационарные очаги инфекции, где достаточно быстро происходят эволюционные изменения взаимоотношений в системе «паразит - хозяин», так как свиньи являются многоплодными и скороспелыми животными и смена поколений у них осуществляется до трех раз за год. Это приводит к существенной вариабельности межпопуляционных взаимоотношений и индукции биоразнообразия молекулярных механизмов адаптации и процессинга вирусного генома. Клинически генетические модификации локальных вариантов PEDV-популяций проявляются в виде изменений эпизоотических особенностей течения инфекционной патологии у различных возрастных групп животных. Модификации РЕDV могут сопровождаться незначительным ослаблением напряженности инфекционного процесса, уменьшением смертности и снижением тяжести патогенеза диарейного синдрома. В то же время, возрастной диапазон тяжелых абдоминальных поражений расширяется с группы новорожденных поросят на откормочных животных старших возрастных групп 28, 32, 70 суток. Использование паллиативного комплекса мер борьбы с ЭДС, включающего «обратное скармливание» переработанного инфицированного биоматериала от переболевших поросят, эрадикацию возбудителя из внешней среды обитания макроорганизма с помощью жесткой тотальной дезинфекции и строжайшего соблюдения ветеринарно-санитарных правил ведения животноводства дает временные положительные результаты, но теоретически является некорректным, так как перезаражение животных приводит к рассеиванию вируса и формированию эндемического очага инфекции. Персистенция вируса в реконвалесцентном организме не зафиксирована, внешняя «неживая» среда может быть только механическим фактором передачи возбудителя инфекции в течение времени сохранения жизнеспособности РEDV. Cтабилизация эпизоотического очага инфекции наиболее часто происходит в результате сочетания трех факторов: а) рассеивания вируса при «обратном скармливании»; б) сохранения вируса во внешней среде в результате некачественной дезинфекции; в) возникновения прослойки не иммунного молодняка от ремонтных свинок, у которых вследствие ювенальной недостаточности функциональной активности иммунной системы, формируется накопление колостральных антител в низких титрах на вирусный антиген в биоматериале при «обратном скармливании». Вследствие отсутствия или низкой напряженности «лактогенного иммунитета», неонатальные поросята, как биоиндикатор наличия PEDV в окружающей среде, начинают репродуцировать вирус в энтероцитах и развивается типичный диарейный синдром ЭДС.

Ключевые слова: диарейный синдром; ЭДС; PEDV; геном-эквивалент; PCR-RT; ELISA

\section{Введение}

Эпидемическая диарея свиней (ЭДС) - эмерджентное высококонтагиозное вирусное зоонозное заболевание свиней всех возрастов с развитием диарейного синдрома. Возбудитель - Porcine epidemic diarrhea virus (PEDV), gender - Alphacoronavirus, family Coronaviridae. Вирионы сложные, плеоморфные, чаще сферической формы 95-130 нм, состоят из нуклеокапсида спиральной симметрии и ЛПО (липопротеидная оболочка s. суперкапсид s. пеплос s. envelope), на поверхности которой имеются радиальные булавовидные пепломеры, длиной 18-23 нм, формирующие «солнечную корону» (Li et al., 2012; Diel et al., 2016).

Наиболее часто употребляемые синонимы для PEDV - инфекции: эпидемическая диарея поросят - ЭДП; эпизоотическая диарея свиней - ЭДС; ТГС-подобное заболевание; Womiting and wasting disease in piglets (англ.); Erbrechen und Kummern bein Saugferkel (нем.) (Li et al., 2012; Carvajal et al., 2015; Diel et al., 2016).

ЭДС впервые зарегистрировали в Англии в 1971 г., затем в Бельгии в 1978 г., где изолировали референтный штамм CV 777. С 1980 по 1990 гг. ЭДС широко распространилась в Европе. С 1995 по 2011 гг. ЭДС проникла в Японию, Корею, Китай и Таиланд. Из Китая северокитайские штаммы PEDV попали в США, что поставило на грань экономической катастрофы свиноводческую отрасль страны. В 2005 г. ЭДС выявлена в России, в 2014 г. в Украине. Глобальное распространение PEDV продолжается. Усилия МЭБ и национальных служб ветеринарной медицины по локализации и контролю над ЭДС малоэффективны (Song et al., 2005; Martelli et al., 2008; Puranaveja et al., 2009; Strizhakova, 2013; Gerber et al., 2014; Wang et al., 2014; Vlasova et al., 2014; Dastjerdi et al., 2015).

PEDV-инфекция у неимунных новорожденных поросят протекает по классическому типу эпизоотического процесса с безэстафетной передачей возбудителя и летальными абдоминальными явлениями, включающими изнурительную водянистую диарею, дегидратацию и истощение, упорную рвоту, тяжелую интоксикацию, инфекционно-аллергические процессы, тонические судороги, глубокую депрессию с исходом в смерть (Kim and Chae, 2003; Martelli et al., 2008; Carvajal et al., 2015; Dastjerdi et al., 2015; Goede et al., 2015; Diel et al., 2016; Masiuk et al., 2017).

Заболеваемость и летальность у новорожденных поросят до 5-дневного возраста могут достигать $100 \%$, однако с увеличением возраста до 14-15 дней, летальность снижается до 3-5\%. Гибель свиней в результате PEDV-инфекции возможна в любом возрасте, однако у животных на откорме летальный исход имеет споради- ческий характер и не представляет экономической угрозы для хозяйства (Martelli et al., 2008; Strizhakova, 2013; Carvajal et al., 2014; Dastjerdi et al., 2015; Bjustrom-Kraft et al., 2016).

ЭДС признана МЭБ и ФАО одним из пяти основных вирозов наряду с АЧС, КЧС, РРСС и цирковирозом, представляющих наибольшую экономическую опасность для свиноводста. PEDV оболочечный одноцепочный РНК-вирус (оцРНК), подверженный частым мутациям (как и все оцРНК вирусы), что приводит к рецидивированию диарейного синдрома и стабилизации эпизоотического очага инфекции, с эндемической формой протекания инфекционного процесса, а неординарно высокая контагиозность возбудителя и его исключительная патогенность для новорожденных поросят приводит к глобализации инфекционной патологии (Martelli et al., 2008; Strizhakova, 2013; Gerber et al., 2014; Goede et al., 2015; Diel et al., 2016).

Эмерджентность возбудителя и особо крупный экономический ущерб, причиняемый трудно управляемой инфекцией, побудили исследователей к интенсивному изучению вируса, поэтому молекулярно-биологические характеристики PEDV достаточно хорошо изучены. Геном PEDV состоит из крупной ( $28 \mathrm{~kb})$ одноцепочной смысловой РНК, которая содержит 7 открытых рамок считывания (ORF1a, ORF1b и ORF2-6). ORF 1a и 1b детерминируют крупные полипротеины (ppla и pplb), которые расщепляются протеазами, кодированными вирусом, на 16 неструктурных белков (nsp1 - nsp16), берущими участие в основных механизмах транскрипции и репликации вирусной PHК. ORFs2-6 кодируют четыре структурных белка, включающих S-гликопротеин (Spike), интегральный Е-белок оболочки (envelope), мембранный М-белок и N-белок нуклеокапсида, а также вспомогательный белок ORF3. Этот белок формирует ионные каналы в мембранах инфицированных клеток кишечника, что является одним из механизмов регуляции продукции вируса. В ходе адаптации и размножения вируса в КК ген ORF3 мутирует и это явление линейно коррелирует с аттенуацией вируса к организму новорожденных поросят (Jung et al., 2015; Gerbera and Opriessniga, 2015; Poonsuk et al., 2016; Diel et al., 2016).

Среди структурных белков S-гликопротеин (150-220 kD) играет важную роль в адсорбции вирионов на энтероцитах кишечника, связывании вируса с клеточными рецепторами, в сплавлении клеточных мембран и пеплоса вируса, и кроме того является основной мишенью для вируснейтрализующих антител (BНА). В его составе идентифицированы 4 ВНА-эпитопа. Для PEDV выявлена связь между белком $\mathrm{S}$, адаптацией к размножению в КК и вирулентностью. Ген S-белка часто подвергается эпидемиологи- 
ческим исследования, включающим филогенетический анализ и ряд молекулярных и серологических диагностических анализов (Chang et al., 2002; Annamalai et al., 2015; Clement et al., 2016; Poonsuk et al., 2016).

Белки М и $\mathrm{N}$ широко используются с целью разработки молекулярных и серологических диагностических тестов для ЭДС. Белок М (20-30 kD) участвует в процессе сборки вирионов, индуцирует синтез ВНА, способных нейтрализовать вирус в присутствии комплемента и $\alpha$-интерферона. Белок N (57-58 kD) - щелочной фосфопротеин, ассоциированный с вирусным геномом, участвует в индукции клеточно-опосредованного иммунитета. Негликолизированный белок Е ЛПО совместно с S-гликопротеином играет важную роль на дебютных этапах репродукции вируса (Knuchel et al., 1992; Li et al., 2007; Diel et al., 2016).

Разработка технологии культивирования вируса в лабораторных условиях является принципиально важным вопросом для дифференциации отдельных устойчивых штаммов, которые спонтанно образуются в ходе мутаций вируса. Первые результаты успешной пролиферации PEDV получены методом пероральной инокуляции новорожденным поросятам гомогената тонкого кишечника от больных животных. Впоследствии удалось адаптировать вирус к КК Vero в присутствии экзогенного трипсина. Размножение вируса сопровождалось ЦПЭ, который выражался в вакуолизации клеток и формировании синцития. Адаптированный к КК Vero вирус можно поддерживать в линиях КК как свиного, так и несвиного происхождения. Поступают сообщения о культивировании в КК утиных фибробластов, обработанных аминопептидазами, а также о способности штамма МК реплицироваться в нейронах новорожденных мышей, после интрацеребрального заражения с явлениями нейровирулентности (Kweon et al., 1994; Quist-Rybachuk et al., 2015; Mahesh, 2015).

После фекально-оральной передачи PEDV репродуцируется в энтероцитах тонкого кишечника и приводит к развитию катарально-геморрагического воспаления с последующим некрозом эпителия кишечника. После инкубационного периода от 12-24 часов до 3-6 суток развиваются клинические признаки заболевания, характерные для ЭДС и включающие водянистую изнурительную диарею, упорную рвоту, интоксикацию, обезвоживание, истощение, тяжелейшую депрессию и высокую летальность у новорожденных поросят. В благоприятных случаях заболевание продолжается 5-10 дней и завершается выздоровлением с постинфекционной астенией и снижением продуктивности. Выделение PEDV с фекалиями наблюдается на протяжении 6-30 суток. Затем выделение прекращается и реконвалесценты освобождаются от вируса (Knuchel et al., 1992; Jung et al., 2015; Diel et al., 2016; Tun et al., 2016).

Все штаммы ЭДС, выделенные в различных странах мира, практически идентичны по антигенной структуре и представляют собой один серотип вируса. Сравнение нуклеотидных последовательностей генов $\mathrm{N}$ и $\mathrm{S}$, а также аминокислотных последовательностей их продуктов у прототипного штамма CV 777, корейского Chinju 99 и нескольких эпизоотических изолятов корейского и японского происхождения обнаружило высокую (до 96,7\%) гомологию (Kim and Chae, 2003; Li et al., 2012; Wang et al., 2014; Zhang et al., 2015).

Особую опасность представляет мутационный потенциал вирусной популяции PEDV, в связи с формированием эндемических очагов инфекционной патологии и рецидивированием диарейного синдрома с интервалом 4-12 месяцев. Отсутствие эффективных, кардинально обрывающих эпизоотическую цепь мероприятий специфической профилактики при любых генетических вариантах возбудителя способствует интенсивному распространению вироза в хозяйствах, делая эпизоотическую ситуацию трудно управляемой с неэффективными мерами борьбы и профилактики. Существующие методы создания лактогенного иммунитета с помощью «обратного скармливания», согласно ветеринарному законодательству Украины, являются архаичными и теоретически подрывают основы биобезопасности и основополагающие противоэпизоотологические принципы борьбы с инфекцией. Реальное прогрессивное распространение данной инфекции показывает крайнюю необходимость применения паллиативных методов борьбы с PEDV, которые могут включать в себя компоненты стратегии «обратного скармливания» и ветеринарно-санитарные меры по эрадикации вируса во внешней среде. Существующие вакцинные препараты в условиях широкого эспериментального применения являются малоэффективными, а иногда оказывают негативное влияние, не обеспечивая надежный протективный иммунитет как у новорожденных поросят, так и у промышленного стада (Arriba et al., 2002; Stevenson et al., 2013; Strizhakova, 2013; Goede and Morrison, 2016; Langel et al., 2016; Tun et al., 2016; Srijangwad et al., 2017).

Цель статьи - охарактеризовать клинико-эпизоотологические особенности диарейного синдрома, индуцированного PEDV, провести мониторинг эндемического течения ЭДС на примере крупного современного свинокомплекса и охарактеризовать этиопатогенез заболевания у животных разных возрастных групп при стабилизации эпизоотического очага инфекции.

\section{Материал и методы исследований}

Экспериментальное исследование биоматериала от больных животных проведено в НИЦ биобезопасности и экологического контроля ресурсов АПК Днепропетровского ГАЭУ. Выявление, идентификация и дифференциация PEDV в биоматериале (кишечник, внутренние органы, фекалии) и его количественная характеристика осуществлены методом PCR-RT с помощью тест-системы «Bio-T kitßPEDV all - TGEV» («Biosellal», Франция) на амплификаторе CFX 96 Real-Time System фирмы Bio Rad (CША).

Серодиагностику ЭДС проводили методом ELISA с использованием иммуноферментного анализатора-фотометра ELx800 («BioTek», США) и тест-системы «ID Screen PEDV Indirect» («ID.vet», Франция). Согласно рекомендациям производителя, сыворотки считаются положительными (содержащими специфические иммуноглобулины к антигенам вируса в титре $1: 200)$, по ЭДС при значении S/P образца выше 0,4 Ед.

Состав микробионтов содержимого кишечника поросят исследовали с помощью стандартных микробиологических методик (Gerhardt et al., 1984). Патогенность изолированных эпизоотических культур микроорганизмов определяли в биопробе на лабораторных животных.

Статистическую обработку полученных результатов проводили с помощью пакета Statistica 6.0 (StatSoft Inc., USA). Для сравнения результатов использовали критерий Стьюдента и его непараметрический аналог - критерий Уилкоксона. Выборочные параметры, указанные в тексте, имеют следующие обозначения: х выборочное среднее, SE - стандартная ошибка среднего. Различия считали статистически достоверными при $\mathrm{P}<0,05$.

\section{Результаты}

Мониторинговые исследования особенностей энзоотического течения ЭДС при стабилизации инфекционного очага проводили в одном из свинокомплексов Запорожской области в течение 2015-2017 годов. В хозяйстве на высоком уровне поддерживалась ветеринарно-санитарная культура ведения свиноводства, стандартные меры биобезопасности соблюдались должным образом в соответствии с требованиями ветеринарного законодательства и эпизоотической ситуации. Животные были надежно защищены от проникновения внешней инфекции и находились под постоянным контролем службы ветеринарной медицины. Хозяйство оценивалось как благополучное относительно острых и хронических инфекций. В зимне-весенний период 2015 г. (февраль - март) на свинокоплексе, где проводила клинико-эпизоотологический мониторинг ветеринарная служба предприятия, выявлено, что у свиней появилась инфекционная патология с диарейным синдромом. Заболевание возникло внезапно с массовым охватом поголовья, ранее подобная инфекционная патология не встречалась. Наиболее уязвимыми для инфекции оказались новорожденные поросята, 
которые погибали уже на первый - второй день жизни, заболеваемость и летальность у них доходили до 100\%. В качестве основных симптоматических признаков PEDV-инфекции зарегистрированы водянистая диарея и рвота, а также быстрая поголовная гибель новорожденных поросят до 1-5-дневного возраста. При этом смертность среди 6-10-дневных поросят составила 50-60\%, а среди 10-15-дневных - 30\%. Падеж среди более взрослых свиней составил около 3-4\% при относительно легком течении диарейного синдрома.

Результаты мониторинга пораженной группы животных показали, что диарея достаточно широко проявлялась у свиней всех возрастов, но яркие клинические проявления в тяжелой форме отмечались только у отдельных особей. При этом гибели среди свиней старших возрастных групп не зафиксировано. Симптомокомплекс кишечного расстройства включал быстро проходящую водянистую диарею и рвоту без тяжелых патофизиологических организменных отклонений от физиологической нормы, температурная реакция отсутствовала, незначительно снизился аппетит, о чем свидетельствовало уменьшение объема потребляемого корма, объемы потребления корма незначительно уменышились, поведенческие реакции не изменились, признаки депрессии не выявлены. Через 5-7 суток после появления первых случаев относительно легкого клинического течения диарейного синдрома состояние животных старших возрастных групп нормализовалось, расстройство ЖКТ не представляло опасности для жизни и продуктивности животных, восстановление нарушенных физиологических функций происходило самопроизвольно.

В то же время, диарейный синдром у новорожденных поросят протекал сверхостро, сопровождался частыми водянисто-слизистыми дефекациями зеленовато-желтого цвета, прогрессирующей дегидратацией и истощением, мучительной рвотой и абдоминальными болями, редкими тоническими судорогами, интоксикацией, общим угнетением при полном сохранении сознания и тактильной чувствительности (рис. 1). Температура находилась в пределах нормы, перед смертью снижалась.

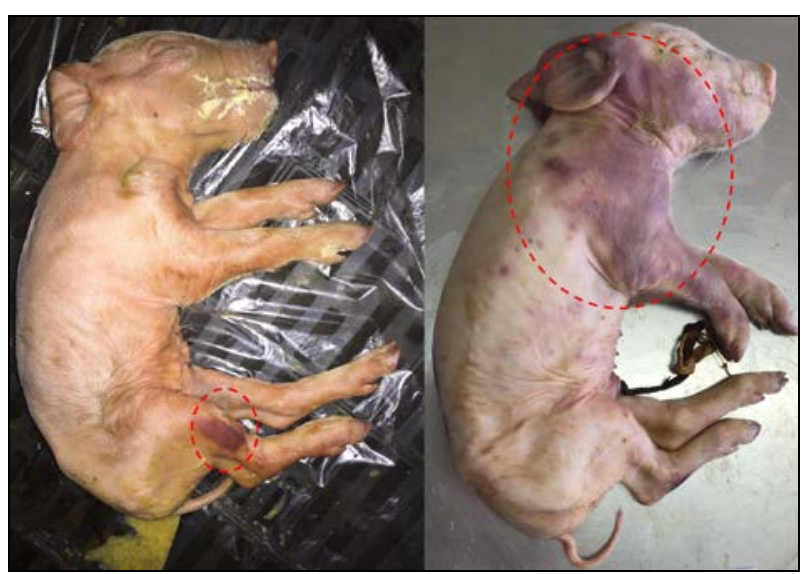

Рис. 1. Трупы новорожденных поросят, павших от ЭДС

При патологоанатомическом осмотре трупы были в состоянии кахексии и дегидратации. Кожа истонченная, сморщенная, неэластичная, бледная с желтоватым оттенком, с контурирующими костными образованиями от морды до седалищных бугров, глаза запавшие. Признаков конъюнктивита и ринита не выявлено. На коже у поросят обнаруживали ограниченные припухлости фиолетово-багрового цвета с желеобразным подкожным отеком инфекционно-аллергической природы.

Таким образом, одной из основных причин летального исхода инфекции является метаболическое истощение организма поросят. Инфекционный агент - высокопатогенный и облигатно летальный для новорожденных животных, индуцирует критические нарушения, не совместимые с жизнью поросят. Патологоанатомические исследования поросят с летальным исходом показали наличие признаков инфекционного патогенеза (рис. 2). Кровь не свернувшаяся, светлая, кровоизлияний на коже и в подкожной клетчатке нет. Патогномоничные изменения локализованы в тонкой кишке в виде чрезвычайно интенсивного катарально-геморрагического воспаления с десквамацией эпителия и истончением кишечной стенки. У поросят, павших от диареи в 5-дневном возрасте, катарально-геморрагическое воспаление обнаружено также и в толстой кишке. В желудке не установили патологических изменений слизистой оболочки, наполнение желудка слизистым содержимым не отличалось от нормы. Регионарные лимфоузлы отечны и гиперемированы. В других внутренних органах патологических нарушений не обнаружено. В частности, селезенка не увеличена, ярко-красного цвета; печень не увеличена, с незначительными сероватыми участками белково-липидной дистрофии; почки и легкие соответствовали норме. В ткани сердца обнаружены участки дегенеративного перерождения. Во внутренних полостях незначительное количество транссудата.

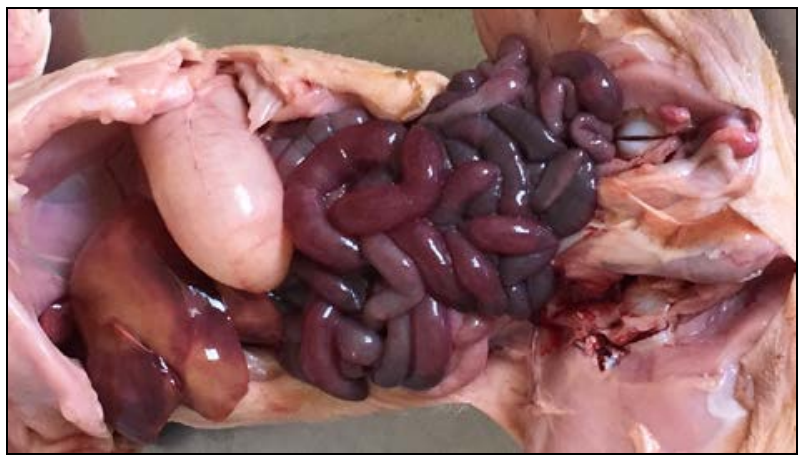

Рис. 2. Патологоанатомические изменения внутренних органов поросенка 5-дневного возраста, павшего от ЭДС

Индикацию возбудителя проводили в НИЦ ДГАЭУ в совместном гомогенате из двух биоматериалов образцов тонкой кишки тканей поросят, павших от диарейного синдрома на вторые сутки жизни, с помощью PCR-RT. В пробах тонкого кишечника поросят идентифицирован PEDV в количестве 7,0 × $10^{2}$ геном-эквивалентов (г. э.) в одном грамме, что является достаточным основанием для установления позитивного результата инфекции PEDV.

C целью определения широты распространения инфекции среди восприимчивых животных проведена ретроспективная сероиндикация IgG к АГ капсида PEDV в ELISA. Для проведения серологических исследований отбирали образцы крови у $10 \%$ животных из свинарника, в котором зафиксировано клиническое проявление заболевания ( $\mathrm{n}=80)$ методом рандомизированной выборки. Результаты серологического исследования показали наличие диагностических титров у 42\% образцов в разведении $1: 200$, что подтвердило предварительный комплексный диагноз на ЭДС. В 76\% проб фекалий от этих же животных методом PCR-RT идентифицирована РНК PEDV в концентрации $1,86 \times 10^{7} \pm 0,14 \times$ $10^{6}$ г. э./г биологического материала.

Для изучения состава видового состава микроорганизмов кишечной трубки отобрали биоматериал (пораженный кишечник и фекалии) у 13 павших от ЭДС поросят 3-8-суточного возраста и провели бактериологическое исследование общепринятыми методами оценки видового состава микроорганизмов, населяющих пищеварительный тракт (табл. 1). При бактериологическом обследовании общепринятыми методами содержимого кишечника и фекалий у поросят, павших от ЭДС, не были изолированы физиологически полезные микробионты: аэрококки (Aerococcus viridans), лактобактерии и бифидобактерии. В содержимом кишечника не выявлены плесневые грибы и дрожжи. Кишечная микрофлора представлена стандартной транзиторной микрофлорой, попавшей в пищеварительный тракт поросят из окружающей среды, преимущественно она состояла из гнилостных микроорганизмов с высокой ферментативной активностью. Изолированы бактерии семейства Enterobacteriaceae, Bacillaceae, Coccaceae. Культуры прокариот обладали типичными для вида морфотинкториальными, культуральными и биохимическими свойствами. Высокой глико- 
литической активностью характеризовались культуры C. perfringens, сильно выраженным протеолитическим потенциалом обладали культуры антракоидных бацилл, E. coli и P. vulgaris. При исследовании патогенных свойств идентифицированных культур прокариот на белых мышах гибели инфицированных животных не отмечали в течение пяти суток наблюдения. При посеве культур на 5\% кровяной МПА гемолиз не обнаружен, что является показателем апатогенности кишечной микрофлоры.

\section{Таблица 1}

Видовой состав микробиоценоза кишечника поросят, павших от ЭДС $(\mathrm{n}=13)$

\begin{tabular}{|c|c|c|c|c|c|c|c|c|c|c|c|c|c|}
\hline \multirow{2}{*}{ Название } & \multicolumn{13}{|c|}{ Номер биоматериала } \\
\hline & 1 & 2 & 3 & 4 & 5 & 6 & 7 & 8 & 9 & 10 & 11 & 12 & 13 \\
\hline $\begin{array}{l}\text { Aerococcus } \\
\text { viridans }\end{array}$ & - & - & - & - & - & - & - & - & - & - & - & - & - \\
\hline Lactobacillus & - & - & - & - & - & - & - & - & - & - & - & - & - \\
\hline Bifidobacterium & - & - & - & - & - & - & - & - & - & - & - & - & - \\
\hline Escherichia coli & + & + & + & + & + & + & + & + & + & + & + & + & + \\
\hline Proteus vulgaris & + & + & + & + & + & + & + & + & + & + & + & + & + \\
\hline $\begin{array}{l}\text { Clostridium } \\
\text { perfringens }\end{array}$ & + & + & + & + & + & + & - & + & - & + & + & + & - \\
\hline Bacillus cereus & - & - & - & - & + & + & + & + & - & + & + & + & + \\
\hline Bacillus subtilis & - & - & - & + & - & + & - & - & + & + & + & + & + \\
\hline Bacillus mycoides & + & - & + & + & + & - & - & + & + & - & + & + & - \\
\hline $\begin{array}{l}\text { Bacillus } \\
\text { megaterium }\end{array}$ & - & - & + & + & + & + & + & - & + & - & + & - & + \\
\hline Enterococcus & + & + & + & + & - & + & - & + & - & + & + & + & - \\
\hline Staphylococcus & + & + & - & - & + & - & + & + & + & - & - & + & - \\
\hline
\end{tabular}

Примечание: “+”- наличие, “-”- отсутствие бактерии.

Результаты комплексного диагноза ЭДС-позитивных образцов среди ранее благополучного поголовья свиней приняты в качестве основного аргумента в выборе решения о санации хозяйства от зарегистрированного вируса методом «обратного скармливания» и эрадикации возбудителя из экосистемы обитания свиней без применения вакцин.

На первом этапе с помощью PCR-RT определили концентрацию вируса в биоматериале для «обратного скармливания». Исследованию подлежали ткани тонкого кишечника 12 2-3-дневных поросят, павших от ЭДС. Результаты молекулярно-генетического анализа показали следующие значения содержания PEDV в тонкой кишке павших от ЭДС новорожденных поросят (г. э./г, рис. 3): $1,69 \times 10^{5} ; 4,55 \times 10^{5} ; 5,29 \times 10^{5} ; 8,30 \times 10^{5} ; 1,01 \times 10^{6} ; 1,42 \times 10^{6} ;$ $2,60 \times 10^{6} ; 4,79 \times 10^{6} ; 4,70 \times 10^{7} ; 9,67 \times 10^{7} ; 9,79 \times 10^{7} ; 1,01 \times 10^{8}$.

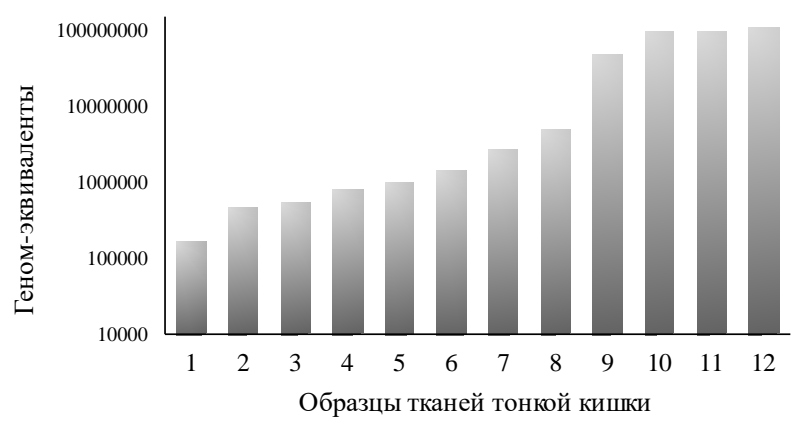

Рис. 3. Концентрация геном-эквивалентов PEDV в образцах тонкой кишки павших от ЭДС новорожденных поросят

Вирусная нагрузка в пораженных тканях колеблется в широких пределах, от 5 до $8 \lg$ вирионов в грамме биоматериала, при этом диапазон $\mathrm{x} \pm \mathrm{SE}=4,11 \times 10^{6} \pm 3,42 \times 10^{5}$ г. э./г.

Процедуру «обратного скармливания» проводили с использованием биоматериала от павших новорожденных поросят. Гомогенат биоматериала кишечной трубки в состоянии катарально-геморрагического воспаления изготавливали на измельчителе тканей РТ-2. Из полученного гомогената ex tempere готовили водную суспензию с содержанием возбудителя в пределах $6 \mathrm{lg}$ вирионов в грамме конечного продукта. С целью формирования эффективно- го колострального иммунитета у новорожденных поросят всех супоросных свиноматок не позднее двух недель до опороса инфицировали per os подготовленным гомогенатом в виде водной суспензии, содержащей известную концентрацию эпизоотического варианта PEDV. Одновременно с мероприятиями, направленными на создание коллективного иммунитета у животных, с целью снижения уровня прессинга и предупреждения распространения PEDV на свиноводческом предприятии, согласно рекомендациям ветеринарного законодательства Украины, проведена предельно тщательная механическая очистка животноводческих помещений и строжайшая тотальная дезинфекция, с терминальным контролем качества дезинфекции и подтверждением факта эрадикации PEDV из окружающей среды с помощью PCR-RT. Возбудитель выявлен только на одном из элементов внутреннего оборудования в смывах с пластикового пола без стока для мочи.

Все павшие от ЭДС животные были утилизированы как источник инфекции. Для подтверждения или опровержения факта персистенции PEDV в организме животных-реконвалесцентов методом PCR-RT проведено исследование 68 образцов фекалий от переболевших свиней различных возрастных групп, начиная от поросят на подсосе до супоросных свиноматок и ремонтного молодняка. Результаты исследования показали отсутствие PEDV в образцах. Кроме этого, 14 наименее продуктивных животныхреконвалесцентов, отнесенных к санитарному браку, отобранных из всех технологических групा содержания тестировали с помощью PCR-RT на наличие PEDV в слизистой оболочке кишечника, регионарных лимфоузлов, печени, селезенки и костного мозга. Ни в одном из исследуемых объектов вирус не обнаружен. Предпринятые энергичные меры безвакцинного эпизоотического воздействия на функционирование эпизоотической цепи привели к тому, что диарейный синдром PEDV-этиологии был клинически купирован.

Однако нестабильное эпизоотическое благополучие сохранялось относительно недолго (в течение 6 месяцев), до того момента, пока в основное стадо не ввели осемененных ремонтных свинок. В 4 гнездах из 64 возникла типичная клиническая картина ЭДС, с последующим распространением инфекции на других восприимчивых животных. Вспышка ЭДС среди новорожденных поросят продолжалась в течение двух недель. Все заболевшие животные убиты и утилизированы, биоматериал (кишечник) использован для «обратного скармливания». Проведена тщательная тотальная дезинфекция с терминальным подтверждением качества санации в PCR-RT. Вследствие предпринятых противоэпизоотических мероприятий инфекционный процесс ЭДС ликвидирован и свинокомплекс оздоровлен.

\section{Обсуждение}

Генетические модификации эпизоотического вируса при стабилизации эпизоотического очага инфекции индуцируют широкую вариабельность клинико-эпизоотического течения инфекционного процесса на разновозрастном поголовье, а также обеспечивают возможность супрессии имунно-биологической резистентности макроорганизма. Быстрая смена туров опороса и многоплодность свиноматок создают плотную и восприимчивую биологическую среду для пассажирования и селекции наиболее трансмиссивных и активно репродуцирующихся генетических вариантов возбудителя, способных колонизировать экологическую нишу обитания (энтероциты кишечника свиней) с развитием летального сверхострого диарейного синдрома у новорожденных поросят, что совпадает с экспериментальными данными, опубликованными Hou et al. (2007), Yu et al. (2008), Di-qiu et al. (2012), Koh et al. (2015), Ouyang et al. (2015), Srijangwad et al. (2017).

Из данных Arriba et al. (2002), Annamalai et al. (2015) и Jung et al. (2015) следует, что возрастные процессы в макроорганизме способствуют повышению иммунобиологической резистентности и обеспечивают устойчивость к развитию острого инфекционного процесса, что приводит к значительному снижению смертности и ослаблению тяжести течения диарейного синдрома. На основании 
собственных исследований и анализа литературных источников мы установили, что персистенции вируса не происходит, макроорганизм полностью освобождается от присутствия чужеродной генетической информации в пространстве, контролируемом собственной иммунной системой (Lin et al., 2015; Langel et al., 2016; Li et al., 2016; Tun et al., 2016). Переживание вируса возможно только на объектах внешней неживой природы с последующим инфицированием восприимчивых организмов и возобновлением цикла репродукции в виде рецидивирования эндемического процесса в стабилизированном очаге вирусной инфекции.

Работы Annamalai et al. (2015), Poonsuk et al. (2016) и Clement et al. (2016) показывают, что в данной парадигме жизненного цикла PEDV наиболее слабым звеном при безвакцинальном способе разрыва эпизоотической цепи являются ремонтные свинки, так как ювенильный, физиологически незрелый организм в условиях неполноценного кормления не может гарантированно синтезировать необходимое количество колостральных Ig, и, тем самым, создать полноценный и напряженный лактогенный иммунитет у новорожденных поросят. Потомство от таких животных представляет группу повышенного риска и может стать дебютным звеном эпизоотической цепи ЭДС (Gerber et al., 2014; Lin et al., 2015; Goede and Morrison, 2016; Langel et al., 2016; Srijangwad et al., 2017).

Учитывая, что PEDV является исключительно контагиозным, высокопатогенным и облигатно летальным инфекционным агентом для неимунных новорожденных поросят, у которых при первичной вспышке ЭДС среди благополучного поголовья индуцирует сверхострое эмерджентное течение диарейного синдрома по классическому типу эпизоотического процесса с безэстафетной передачей возбудителя, заболеваемостью и смертностью до 100\% инфицированных поросят, Martelli et al. (2008), Carvajal et al. (2015) и Diel et al. (2015) считают важнейшим направлением дальнейших биологических исследований мониторинг эпизоотологического процесса при ЭДС. При этом необходимо сосредоточить усилия на углубленном изучении молекулярной биологии возбудителя, корреляционных связей между генетическими характеристиками эпизоотических изолятов PEDV и клинико-эпизоотологическими особенностями инфекционного процесса вируса на различных возрастных группах поросят при пространственно-временной стабилизации очага инфекции с углублением в молекулярную эпизоотологию межпопуляционного взаимодействия PEDV и организма новорожденных поросят (Kweon et al., 1994; Arriba et al., 2002; Suo et al., 2012; Lin et al., 2015; Zhang et al., 2015).

Song et al. (2008), Stevenson et al. (2013) и Diel et al. (2016) считают, что практика ведения свиноводства нуждается в эффективных и основанных на биологии инфекционного агента специфических средствах профилактики. При разработке таких средств они рекомендуют использовать различные облегченные вариации stamping-aut, направленные на эрадикацию возбудителя и создание доступными способами иммунного фона, препятствующего репродукции вируса, и, тем самым, обрывающего эпизоотическую цепь. Это утверждение совпадает с нашими выводами и рекомендациями по борьбе с ЭДС.

Изучение молекулярной эпизоотологии PEDV, индуцирующего классический тип инфекционного процесса без эстафетной передачи возбудителя на восприимчивом поголовье - новорожденных поросятах, которые являются биоиндикатором PEDV, представляет уникальную возможность проследить процесс взаимодействия двух антагонистических популяций микро- и макроорганизмов, выяснить общебиологические закономерности сосуществования популяций микроорганизмов и позвоночных (Arriba et al., 2002; Lin et al., 2015; Clement et al., 2016; Li et al., 2016).

Парадигмальной эпизоотологической особенностью этиопатогенеза ЭДС является узкий временной диапазон летального поражения чувствительных клеток-мишеней кишечника неимунных животных с элиминацией вируса после репродукции, то есть короткий жизненный цикл пребывания вируса в макроорганизме с последующей полной элиминацией возбудителя. Это сводит стратегию борьбы с ЭДС к созданию невосприимчивого макроорганизменного фона (популяционный иммунитет) для вируса и его эрадикации во внешней технологической среде (Clement et al., 2016; Langel et al., 2016; Li et al., 2016; Srijangwad et al., 2017).

В заключение необходимо подчеркнуть, что на современном этапе эволюционного развития PEDV, биологический межвидовой летальный антагонизм между вирусом и неимунными новорожденными поросятами не преодолен, популяция PEDV и организм новорожденных поросят биологически, как несингенные генетические системы, несовместимы и в едином биотопе сосуществовать не могут.

\section{Выводы}

Персистенция PEDV в организме реконвалесцентных животных не зафиксирована, макроорганизм после переболевания полностью освобождается от возбудителя. Формирование стабильного эндемического очага инфекции возможно за счет сохранения вируса на технологических объектах внешней среды и инфицирования неимунных животных, прежде всего новорожденных.

Новорожденные поросята, полученные от ремонтных свинок, представляют повышенную группу риска, так как ювенильные животные с низким уровнем иммунной резистентности при неудовлетворительном кормлении после «обратного скармливания» могут формировать лактогенный иммунитет недостаточной напряженности, и неимунные новорожденные поросята, как биоиндикатор наличия во внешней среде PEDV, становятся дебютным звеном эпизоотической цепи ЭДС.

При стабилизации эпизоотического очага ЭДС во времени и пространстве происходит увеличение инфицирования в результате расширения возрастного диапазона поражения на более старшие возрастные группы (28-70 суток), при этом незначительно снижается тяжесть патогенеза и уменьшается смертность. Из эмерджентного качества патогенез не выходит, что свидетельствует о начальном этапе адаптации и слабой аттенуации популяции PEDV к экосистеме организма поросят.

\section{References}

Annamalai, T., Saif, L. J., Lu, Z., \& Jung, K. (2015). Age-dependent variation in innate immune responses to porcine epidemic diarrhea virus infection in suckling versus weaned pigs. Veterinary Immunology and Immunopathology, 168(3), 193-202.

Arriba, M. L., Carvajal, A., Pozo, J., \& Rubio, P. (2002). Isotype-specific antibody-secreting cells in systemic and mucosal associated lymphoid tissues and antibody responses in serum of conventional pigs inoculated with PEDV. Veterinary Immunology and Immunopathology, 84(1), 1-16.

Arriba, M. L., Carvajal, A., Pozo, J., \& Rubio, P. (2002). Lymphoproliferative responses and protection in conventional piglets inoculated orally with virulent or attenuated porcine epidemic diarrhoea virus. Journal of Virological Methods, 105(1), 37-47.

Bjustrom-Kraft, J., Woodard, K., Giménez-Lirola, L., Rotolo, M., Wang, C., Sun, Y., Lasley, P., Zhang, J., Baum, D., Gauger, P., \& Zimmerman, J. (2016). Porcine epidemic diarrhea virus (PEDV) detection and antibody response in commercial growing pigs. BMC Veterinary Research, 12, 99-107.

Carvajal, A., Argüello, H., Martínez-Lobo, F. J.,Costillas, S., Miranda, R., de Nova, P. J. G., \& Rubio, P. (2015). Porcine epidemic diarrhoea: New insights into an old disease. Porcine Health Management, 1(12), 1-8.

Chang, S. H., Bae, J. L., Kang, T. J., Kim, J., Chung, G. H., Lim, C. W., Laude, H., Yang, M. S., \& Jang, Y. S. (2002). Identification of the epitope region capable of inducing neutralizing antibodies against the porcine epidemic diarrhea virus. Joumal of Molecules and Cells, 14(2), 295-299.

Choudhury, B., Dastjerdi, A., Doyle, N., Frossard, J. P., \& Steinbach, F. (2016). From the field to the lab - An european view on the global spread of PEDV. Virus Research, 226, 40-49.

Clement, T., Singrey, A., Lawson, S., Okda, F., Nelson, J., Diel, D., Nelson, E. A., \& Christopher-Hennings, J. (2016). Measurement of neutralizing antibodies against porcine epidemic diarrhea virus in sow serum, colostrum, and milk samples and in piglet serum samples after feedback. Journal of Swine Health and Production, 24(3), 147-153.

Dastjerdi, A., Carr, J., Ellis, R. J., Steinbach, F., \& Williamson, S. (2015). Porcine Epidemic Diarrhea Virus among farmed pigs, Ukraine. Emerging Infectious Diseases, 21(12), 2235-2237.

Diel, D. G., Lawson, S., Okda, F., Singrey, A., Clement, T., Fernandes, M. H. V., Christopher-Hennings, J., \& Nelson, E. A. (2016). Porcine epidemic diarrhea 
virus: An overview of current virological and serological diagnostic methods. Virus Research, 226(2), 60-70.

Di-Qiu, L., Jun-Wei, G., Xin-Yuan, Q., Yan-Ping, J., Song-Mei, L., \& Yi-Jing, L. (2012). High-level mucosal and systemic immune responses induced by ora administration with Lactobacillus-expressed porcine epidemic diarrhea virus (PEDV) $\mathrm{S}_{1}$ region combined with Lactobacillus-expressed $\mathrm{N}$ protein Applied Microbiology and Biotechnology, 93(6), 2437-2446.

Gerber, P. F., \& Opriessnig, T. (2015). Detection of immunoglobulin (Ig) A antibodies against porcine epidemic diarrhea virus (PEDV) in fecal and serum samples. MethodsX, 2, 368-373.

Gerber, P. F., Gong, Q., Huang, Y. W., Wang, C., Holtkamp, D. \& Opriessnig, T. (2014). Detection of antibodies against porcine epidemic diarrhea virus in serum and colostrum by indirect ELISA. The Veterinary Joumal, 202(1), 33-36.

Goede, D., \& Morrison, R. B. (2016). Production impact and time to stability in sow herds infected with porcine epidemic diarrhea virus (PEDV). Preventive Veterinary Medicine, 123(1), 202-207.

Goede, D., Murtaugh, M. P., Nerem, J., Yeske, P., Rossow, K., \& Morrison, R. (2015). Previous infection of sows with a "mild" strain of porcine epidemic diarrhea virus confers protection against infection with a "severe" strain. Veterinary Microbiology, 176(1), 161-164.

Hou, X.-L., Yu, L. Y., Liu, J., \& Wang, G. H. (2007). Surface-displayed porcine epidemic diarrhea viral (PEDV) antigens on lactic acid bacteria. Journal of Vaccine, 26(1), 24-31.

Jung, K., Annamalai, T., Lu, Z., \& Saif, L. J. (2015). Comparative pathogenesis of US porcine epidemic diarrhea virus (PEDV) strain PC21A in conventional 9-day-old nursing piglets vs. 26-day-old weaned pigs. Veterinary Microbiology, 178(1), 31-40.

Khatri, M. (2015). Porcine Epidemic Diarrhea Virus replication in duck intestina cell line. Emerging Infectious Diseases, 21(3), 549-550.

Kim, O., \& Chae, C. (2003). Experimental infection of piglets with a korean strain of porcine epidemic diarrhoea virus. Journal of Comparative Pathology, 129(1), 55-60.

Knuchel, M., Ackermann, M., Müller, H. K., \& Kihm, U. (1992). An ELISA for detection of antibodies against porcine epidemic diarrhoea virus (PEDV) based on the specific solubility of the viral surface glycoprotein. Veterinary Microbiology, 32(2), 117-134.

Koh, H. W., Kim, M. S., Lee, J. S., Kim, H., \& Park, S. J. (2015). Changes in the swine gut microbiota in response to porcine epidemic diarrhea infection. Microbes and Environments, 30(3), 284-287.

Kweon, C. H., Kwon, B. J., Kang, Y. B., \& An, S. H. (1994). Cell adaptation of KPEDV-9 and serological survey on porcine epidemic diarrhoea virus (PEDV) infection in Korea. Korean Journal of Veterinary Research, 34(2), 321-326.

Langel, S. N., Paim, F. C., Lager, K. M., Vlasova, A. N., \& Saif, L. J. (2016) Lactogenic immunity and vaccines for porcine epidemic diarrhea virus (PEDV): Historical and current concepts. Virus Research, 226, 93-107.

Li, B. X., Ge, J. W., \& Li, Y. J. (2007). Porcine aminopeptidase N is a functional receptor for the PEDV coronavirus. Journal of Virology, 365(1), 166-172.

Li, W., Kuppeveld, F. J. M., He, Q., Rottier, P. J. M., \& Bosch, B. J. (2016) Cellular entry of the porcine epidemic diarrhea virus. Journal of Virus Research, 226, 117-127.

Li, Z.-L., Zhu, L., Ma, J.-Y., Zhou, Q.-F., Song, Y.-H., Sun, B.-L., Chen, R.-A., Xie, Q.-M., \& Bee, Y.-Z. (2012). Molecular characterization and phylogenetic analysis of porcine epidemic diarrhea virus (PEDV) field strains in south China. Virus Genes, 45, 181-185.

Lin, C. M., Annamalai, T., Liu, X., Gao, X., Lu, Z., El-Tholoth, M., Hu, H., Saif, L. J., \& Wang, Q. (2015). Experimental infection of a US spike-insertion deletion porcine epidemic diarrhea virus in conventional nursing piglets and cross-protection to the original US PEDV infection. Veterinary Research, 46, 134-147.
Martelli, P., Lavazza, A., Nigrelli, A. D., Merialdi, G., Alborali, L. G., \& Pensaert, M. B. (2008). Epidemic of diarrhoea caused by porcine epidemic diarrhoea virus in Italy. Veterinary Record, 162(10), 307.

Masiuk, D., Sosnitskiy, A., Kokarev, A., \& Koliada, S. (2017). Experimental infection of pigs porcine epidemic diarrhea virus. Scientific Messenger LNUVMBT named after S. Z. Gzhytskyj, 19(77), 208-213.

Poonsuk, K., Zhang, J., Chen, Q., Gonzalez, W., Correa da Silva Carrion, L., Sun, Y., Ji, J., Wang, C., Main, R., \& Zimmerman, J. (2016). Quantifying the effect of lactogenic antibody on porcine epidemic diarrhea virus infection in neonatal piglets. Veterinary Microbiology, 197, 83-92.

Puranaveja, S., Poolperm, P., Lertwatchharasarakul, P., Kesdaengsakonwut, S. Boonsoongnem, A., Urairong, K., Kitikoon, P., Choojai, P., Kedkovid, R., Teankum, K., \& Thanawongnuwech, R. (2009). Chinese-like strain of porcine epidemic diarrhea virus, Thailand. Emerging Infectious Diseases, 15, $1112-1115$.

Quist-Rybachuk, G. V., Nauwynck, H. J., \& Kalmar, I. D. (2015). Sensitivity of porcine epidemic diarrhea virus (PEDV) to $\mathrm{pH}$ and heat treatment in the presence or absence of porcine plasma. Veterinary Microbiology, 181(3), 283-288.

Song, D. S., Oh, J. S., Kang, B. K., Yang, J. S., Song, J. Y., Moon, H. J., Kim, T. Y., Yoo, H. S., Jang, Y. S., \& Park, B. K. (2005). Fecal shedding of a highly cell-culture-adaptrd porcine epidemic diarrhea virus after oral inoculation in pigs. Journal of Swine Health and Production, 13(5), 269-272.

Srijangwad, A., Stott C. J, Temeeyasen, G, Senasuthum, R, Chongcharoen, W., Tantituvanont, A., \& Nilubol, D. (2017). Immune response of gilts to single and double infection with porcine epidemic diarrhea virus. Archives of Virology, 162, 2029-2034.

Stevenson, G. W., Hoang, H., Schwartz, K. J., Burrough, E. R., Sun, D., Madson, D., Cooper, V. L., Pillatzki, A., Gauger, P., Schmitt, B. J., Koster, L. G., Killian, M. L., \& Yoon, K. J. (2013). Emergence of Porcine epidemic diarrhea virus in the United States: Clinical signs, lesions and viral genomic sequences. Journal of Veterinary Diagnostic Investigation, 25, 649-654.

Strizhakova, O. M. (2013). Vydelenie i identifikacija virusa epizooticheskoj diarei cvinej pri vspyshke v krupnom svinovodcheskom hoziajstve [Isolation and identification of epizootic diarrhea virus in pigs under outbreak at a large farm]. Sel'skokhozyaistvennaya Biologiya, 4, 65-69 (in Russian).

Suo, S., Ren, Y., Li, G., Zarlenga, D., Bu, R., Su, D., Li, X., Li, P., Meng, F., \& Wang, C. (2012). Immune responses induced by DNA vaccines bearing Spike gene of PEDV combined with porcine IL-18. Virus Research, 167(2), 259-266.

Tun, H. M., Cai, Z., \& Khafipour, E. (2016). Monitoring survivability and infectivity of Porcine Epidemic Diarrhea Virus (PEDv) in the infected onfarm Earthen Manure Storages (EMS). Frontiers in Microbiology, 7, 265 276.

Vlasova, A. N., Marthaler, D., Wang, Q., Culhane, M. R., Rossow, K. D., Rovira, A., Collins, J., \& Saif, L. J. (2014). Distinct characteristics and complex evolution of PEDV strains, North America, May 2013 - February 2014 Emerging Infectious Diseases, 20(10), 1620-1628.

Wang, L., Byrum, B., \& Zhang, Y. (2014). New variant of Porcine Epidemic Diarrhea Virus, United States. Emerging Infectious Diseases, 20(5), 917-919.

Yu, L., Zhao, Z., Hou, X., Cao, H., \& Wang, G. (2008). Study on the surface displayed Porcine Epidemic Diarrhea Viral (PEDV) S1 on lactic acic bacteria. Journal of Heilongiiang August First Land Reclamation University, 4, 45-47.

Zhang, X., Pan, Y., Wang, D., Tian, X., Song, Y., \& Cao, Y. (2015). Identification and pathogenicity of a variant porcine epidemic diarrhea virus field strain with reduced virulence. Virology Journal, 12, 88-93. 